\title{
Performance Evaluation of Monolith Based Immobilized Acetylcholinesterase Flow-Through Reactor for Copper(II) Determination with Spectrophotometric Detection
}

\author{
Parawee Rattanakit $^{1}$ and Saisunee Liawruangrath ${ }^{2}$ \\ ${ }^{1}$ School of Science, Walailak University, Nakhon Si Thammarat 80161, Thailand \\ ${ }^{2}$ Department of Chemistry, Faculty of Science, Chiang Mai University, Chiang Mai 50200, Thailand \\ Correspondence should be addressed to Parawee Rattanakit; p_rattanakit@yahoo.com
}

Received 31 October 2013; Revised 22 December 2013; Accepted 25 December 2013; Published 4 February 2014

Academic Editor: Qing Li

Copyright (C) 2014 P. Rattanakit and S. Liawruangrath. This is an open access article distributed under the Creative Commons Attribution License, which permits unrestricted use, distribution, and reproduction in any medium, provided the original work is properly cited.

\begin{abstract}
A monolith based immobilized acetylcholinesterase (AChE) flow-through reactor has been developed for the determination of copper(II) using flow injection spectrophotometric system. The bioreactor was prepared inside a microcapillary column by in situ polymerization of butyl methacrylate, ethylene dimethacrylate, and 2,2-dimethoxy-1,2-diphynyletane-1-one in the presence of 1decanol, followed by vinyl azlactone functionalization and AChE immobilization. The behavior of AChE before and after being immobilized on the monolith was evaluated by kinetic parameters from Lineweaver and Burk equation. The detection was based on measuring inhibition effect on the enzymatic activity of AChE by copper(II) using Ellman's reaction with spectrophotometric detection at $410 \mathrm{~nm}$. The linear range of the calibration graph was obtained over the range of $0.02-3.00 \mathrm{mg} \mathrm{L}^{-1}$. The detection limit, defined as $10 \%$ inhibition $\left(I_{10}\right)$, was found to be $0.04 \mathrm{mg} \mathrm{L}^{-1}$. The repeatability was $3.35 \%(n=5)$ for $1.00 \mathrm{mg} \mathrm{L}^{-1}$ of copper(II). The proposed method was applied to the determination of copper(II) in natural water samples with sampling rate of $4 \mathrm{~h}^{-1}$.
\end{abstract}

\section{Introduction}

Nowadays, environmental contamination from toxic heavy metal ions is a worldwide concern [1]. Because of their less biosusceptibility and toxic effect on organisms, the potential risk of heavy metals to human health and ecology has received much attention [2]. Several conventional methods of high precision analysis of heavy metal, that is, gas and liquid chromatography, atomic absorption spectrometry, and inductively coupled plasma mass spectrometry, require highskilled personnel and complex and expensive equipment. Besides, complicated sample pretreatment is necessary to make the procedure more time and costs consuming [3]. To solve the above mentioned problems, biosensors are being developed and utilized alternatively for determination of heavy metals due to their exceptional performance capabilities, which include high specificity and sensitivity, rapid response, low cost, relatively compact size, and user-friendly operation $[4,5]$.
A lot of publications have been reported on the use of biosensor based on immobilized enzyme for heavy metals determination. Many enzymes have been investigated for this application such as urease $[3,6-8]$, glucose oxidase [9-11], invertase [12], and acetylcholinesterase [13]. Most of them are focused on electrochemical methods $[1,3,8,9,13]$ but a few literature supports on spectrophotometric detection due to simple, easy to implement and cost effective [14]. Kuswandi [15] described the development of a simple optical fiber biosensor for the determination of various heavy metal ions $\left(\mathrm{Hg}^{2+}, \mathrm{Ag}^{+}, \mathrm{Cu}^{2+}, \mathrm{Ni}^{2+}, \mathrm{Zn}^{2+}, \mathrm{Co}^{2+}\right.$ and $\left.\mathrm{Pb}^{2+}\right)$ using urease immobilized in ultrabind membrane. The $\mathrm{pH}$ change resulting from the biocatalytic hydrolysis of urea was monitored at $615 \mathrm{~nm}$ using commercial $\mathrm{pH}$ indicator strip. A flow injection system for copper(II) ion based on immobilized urease onto seven modified acrylonitrile copolymer membrane was studied by Godjevargova et al. [2]. Although the above methods are based on flow injection (FI) system which is superior to the batch-wise methods in that they provide 
relatively high sample throughput, low reagents and sample consumptions, low waste production, low analysis time, and cost effectiveness, but the modification of the membrane and immobilization of an enzyme procedures are complicated and time consuming.

Currently, monolithic materials have been utilized as matrix supports for enzyme immobilization due to their great flexibility in terms of chemical functionality and of the morphology that can be achieved readily during in situ preparation [16]. Moreover, polymer monolith presents low flow resistance, high reaction efficiency, and good flowthrough properties [17]. The application of monoliths in enzyme immobilisation has proved to be successful for environmental analysis and separation science by using a lot of polymer monoliths such as poly(glycidyl methacrylate-coethylene dimethacrylate) [18], poly(butyl methacrylate-coethylene dimethacrylate) [19], and rigid macroporous monoliths consisting of 2-vinyl-4,4-dimethyl-azlactone, ethylene dimethacrylate, and acrylamide or 2-hydroxyethyl methacrylate $[20]$.

In this work, a simple bioreactor incorporating with in situ preparation of polymer monolith and subsequently AChE immobilization is developed. The monolith was prepared using butyl methacrylate as monomer, ethylene dimethacrylate as cross-linker, 2,2-dimethoxy-1,2-diphenylethane-1-one as the initiator, and 1-decanol as solvent. Photografting of vinyl azlactone was then used to selectively functionalize the monolith to enable the subsequent immobilization of AChE. The proposed method was adopted to measure the inhibition of AChE to determine copper(II) using Ellman's reaction [21] with spectrophotometric detection at $410 \mathrm{~nm}$.

\section{Experimental}

2.1. Chemicals. Milli-Q water $(18 \mathrm{M} \Omega \mathrm{cm})$ was used through out. All chemicals were of analyticalreagent grade and used without any further purification. Acetylcholinesterase (AChE) from electric eel (E.C. 3.1.1.7; type VI-S, $500 \mathrm{U}$ ), acetylthiocholine iodide (ATChI), and 5, $5^{\prime}$-dithiobis2-nitrobenzoic acid (DTNB) were all purchased from Sigma Chemical (St. Louis, MO, USA). Potassium dihydrogen phosphate $\left(\mathrm{KH}_{2} \mathrm{PO}_{4}\right)$ and potassium hydroxide $(\mathrm{KOH})$ were supplied by $\mathrm{BDH}$ (Poole, England). Monoethanolamine was obtained from Aldrich. Butyl methacrylate (BuMA), ethylene glycol dimethacrylate (EDMA), 2,2-dimethoxy-1,2diphenylethane-1-one (DMPA), 1-decanol, ethanol, methanol, 3-(trimethoxysilyl)-propyl methacrylate, and ethylenediaminetetraacetic acid (EDTA) were purchased form Sigma Aldrich (St. Louis, MO, USA). 2-Vinyl-4,4-dimethylazlactone was purchased from Polysciences Asia Pacific, Inc. (Taipei, Taiwan). Copper(II) standard solution (1000 $\left.\mathrm{mg} \mathrm{L}^{-1}\right)$ was obtained from Ajax Finechem (NSW, Australia).

2.2. Preparation of Polymer Monolith, Photografting of 2-Vinyl-4,4-dimethylazlactone and Enzyme Immobilization. The internal wall surface of the capillary column $(0.5 \mathrm{~mm}$ i.d., Blaubrand intraMARK, Germany) was first vinylised with 3-(trimethoxysilyl) propyl methacrylate to enable covalent attachment of the monolith to capillary surface. The poly(butyl methacrylate-co-ethylenedimethacrylate) or poly(BuMA-co-EDMA) was prepared by photoinitiation using DMPA as the initiator. The methacrylate-based monolith was prepared from a mixture of $\operatorname{BuMA}(24 \%$, w/w), EDMA $(16 \%$, w/w), 1-decanol $(60 \%$, w/w), and DMPA (1\% with respect to monomer). The polymerization mixtures were sonicated and deaerated by purging with a stream of nitrogen. The capillary $(4 \mathrm{~cm})$ was then completely filled with the polymerization mixture and placed under the UV-light at a wavelength of $365 \mathrm{~nm}$ and irradiating for $3 \mathrm{~min}$ at room temperature. The unreacted materials were flushed out with methanol after completion of the polymerization.

To enable the covalent immobilization of AChE, the surface of the polymer monolith was first activated by photografting with the reactive monomer 2-vinyl-4,4dimethylazlactone, using a procedure modified from that described by Peterson et al. [19] and Logan et al. [22]. A solution of 2-vinyl-4,4-dimethylazlactone was pumped through the poly(BuMA-co-EDMA) monolith at flow rate $0.5 \mu \mathrm{L} \mathrm{min}^{-1}$ for $30 \mathrm{~min}$. The capillary filled with grafting mixture was then placed under the UV lamp and irradiated for $1 \mathrm{~min}$. After the grafting was completed, the monoliths were washed with acetone to remove the excess reagent.

A $180 \mu \mathrm{L}$ aliquot of $0.025 \mathrm{U}_{\mu} \mathrm{L}^{-1}$ AChE enzyme solution prepared in $0.1 \mathrm{M}$ phosphate buffer $\mathrm{pH} 7.0$ was loaded into the functionalized monolith at a flow rate of $0.5 \mu \mathrm{L} \mathrm{min}^{-1}$ for $3 \mathrm{~h}$ and then washed with phosphate buffer at a flow rate of $10 \mu \mathrm{L} \mathrm{min}^{-1}$. The monolith was then rinsed with 1.0 M ethanolamine at a flow rate of $0.5 \mu \mathrm{L} \mathrm{min}^{-1}$ for $1 \mathrm{~h}$ to quench all unreacted azlactone functionalities again followed by washing with phosphate buffer at $10 \mu \mathrm{L} \mathrm{min}^{-1}$ to remove excess reagent. The bioreactor was conditioned with phosphate buffer $(0.1 \mathrm{M} \mathrm{pH} 8.0)$ before use and stored at $4^{\circ} \mathrm{C}$ in phosphate buffer $(0.1 \mathrm{M} \mathrm{pH} \mathrm{7.0)}$ containing $0.1 \%$ sodium azide.

\subsection{Enzyme Activity Assay and Measurement of Free and} Immobilized Enzyme Inhibition. The enzyme activity measurements were carried out to evaluate the performance of the immobilized enzyme by comparing with free enzyme in a solution system. In order to evaluate the immobilized enzyme activity, a continuous flow injection system that consists of a microsyringe pump (Fusion X-100, CHEMYX Inc., US), two micro injection valves with sample loops of $40 \mu \mathrm{L}$ and $50 \mu \mathrm{L}$, and enzyme immobilized monolith bioreactor equipped with a home-made colorimetric detector [23] was used. The colorimeter had a light emitting diode (LED) as light source and a photodiode as light sensor. The signal generated is converted and integrated using the specially made software program. The absorption was monitored at $410 \mathrm{~nm}$. The PTFE tubing with $0.3 \mathrm{~mm}$ i.d. (Supelco) was used for the flow lines. The schematic diagram of flow injection system is shown in Figure 1.

A series of substrate concentrations $(0.5-20.0 \mathrm{mM})$ were injected onto the monolith using 6-port valve injector. The carrier buffer solution was propelled through the system at 


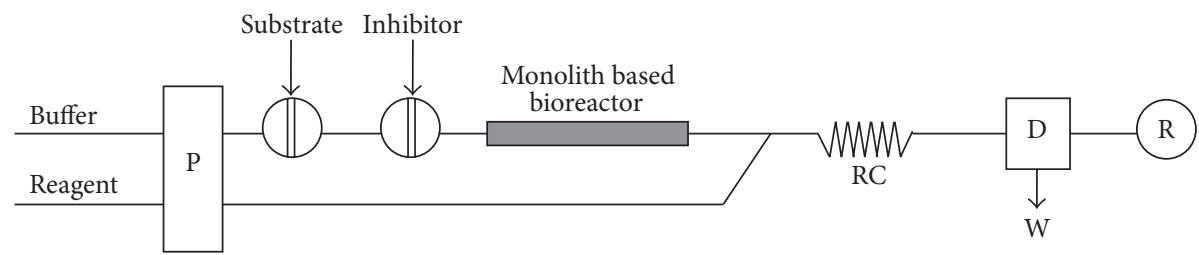

FIGURE 1: The flow injection manifold for copper(II) determination. P, syringe pump; RC, reaction coil; D, detector (colorimeter); R, recording system; W, waste.

$50 \mu \mathrm{L} \mathrm{min}{ }^{-1}$. For analysis of copper(II) inhibition, ATChI (the substrate) was first introduced onto the AChE functionalised monolith bioreactor via the first injection valve equipped with $40 \mu \mathrm{L}$ injection loop. The product, thiocholine from the enzymatic hydrolysis reaction was then continuously mixed with DTNB, flowing at $20 \mu \mathrm{L} \mathrm{min}{ }^{-1}$, to form a yellow colour nitrobenzoate. The absorbance $\left(A_{0}\right)$ was measured at $410 \mathrm{~nm}$ and related to the activity of uninhibited enzyme. After which, a solution of copper(II) was pumped through the monolith bioreactor via the second injection valve equipped with $50 \mu \mathrm{L}$ injection loop at a flow rate of $5 \mu \mathrm{L} \mathrm{min}{ }^{-1}$ to allow $10 \mathrm{~min}$ incubation time. Then the column was washed with phosphate buffer flowing at $50 \mu \mathrm{L} \mathrm{min}^{-1}$ for $2 \mathrm{~min}$. Finally, the same concentration of ATChI was injected to the system and the product was measured again, as described earlier, and a smaller absorbance $\left(A_{1}\right)$ was recorded. Restoration of the inhibition $\mathrm{AChE}$ reactor was carried out by passing $0.5 \mathrm{mM}$ EDTA solution through the column at a flow rate of $20 \mu \mathrm{L} \mathrm{min}^{-1}$ for $1 \mathrm{~min}$ to achieve over $95 \%$ of the starting activity. According to the difference between the absorbance measured before $\left(A_{0}\right)$ and after $\left(A_{1}\right)$ the passage of copper through the reactor, the percentage inhibition can be calculated using the following equation:

$$
I \%=\frac{A_{0}-A_{1}}{A_{0}} \times 100 .
$$

The measurements for free enzyme were performed in a disposable cuvette which contained $20 \mu \mathrm{L}$ of $0.25 \mathrm{U} \mu \mathrm{L}^{-1}$ of AChE, $50 \mu \mathrm{L}$ of $100 \mathrm{mg} \mathrm{L}^{-1}$ of DTNB, to which different volumes of a standard copper(II) were added to give the required concentrations in a total volume of $2 \mathrm{~mL}$ of $0.1 \mathrm{M}$ phosphate buffer, $\mathrm{pH} 8.0$ solution. After an incubation time of $10 \mathrm{~min}$ at room temperature, $20 \mu \mathrm{L}$ aliquots of ATChI standards were added to the cuvette in order to generate a range of substrate concentrations $(0.5-20.0 \mathrm{mM})$. The absorptions were performed at $410 \mathrm{~nm}$.

The kinetics parameters such Michaelis constant $\left(K_{m}\right)$ and maximum reaction velocity $\left(V_{\max }\right)$ were determined from Lineweaver and Burk double reciprocal plot analyzed over a range of acetylthiocholine concentrations. The chart of Lineweaver and Burk in which the lines obtained cross the $y$-axis and that of the $X$-coordinates in two distinct points which correspond, respectively, to $1 / V_{\max }$ and $-1 / K_{m}$ led to the determination of $V_{\max }$ and $K_{m}$. These data were obtained by means of spectrometric absorption of the enzyme in
TABLE 1: Kinetics constants of $K_{m}$ and $V_{\max }$ for free AChE in solution (A) and AChE immobilized monolith (B).

\begin{tabular}{lcc}
\hline & $K_{m}\left(\times 10^{-4} \mathrm{M}\right)$ & $V_{\max }\left(\mathrm{mol} \mathrm{L}^{-1} \mathrm{~min}^{-1}\right)$ \\
\hline (A) & 2.3 & 13.6 \\
Free AChE & 2.3 & 9.3 \\
copper(II) $0.5 \mathrm{mg} \mathrm{L}^{-1}$ & 2.3 & 7.3 \\
copper(II) $1.0 \mathrm{mg} \mathrm{L}^{-1}$ & 2.3 & 5.5 \\
copper(II) $2.0 \mathrm{mg} \mathrm{L}^{-1}$ & & \\
(B) & 2.1 & 1.9 \\
Immobilized $\mathrm{AChE}^{-1}$ & 2.1 & 1.3 \\
copper(II) $0.5 \mathrm{mg} \mathrm{L}^{-1}$ & 2.1 & 0.9 \\
copper(II) $1.0 \mathrm{mg} \mathrm{L}^{-1}$ & 2.1 & 0.7 \\
copper(II) $2.0 \mathrm{mg} \mathrm{L}^{-1}$ & &
\end{tabular}

solution and attached to the monolith under two experimental conditions involving the presence or absence of enzyme inhibitor.

\section{Results and Discussion}

3.1. Evaluation of the Immobilized Enzyme Inhibition. The determination of copper(II) levels based on AChE spectrometric sensor, where the substrate acetylthiocholine iodide is catalytically hydrolysed in the presence of AChE to produce thiocholine which reacted with DTNB to form yellow product of 5-thio-2-nitrobenzoated that can be spectrometrically detected at $410 \mathrm{~nm}$, was used in this work. The kinetics of free and immobilized enzymes, which were determined in the absence and presence of $\mathrm{Cu}$, obeyed the Lineweaver-Burk equation [24]. The kinetics parameters are given in Table 1 and the Lineweaver-Burk plots for the enzyme complexes are shown in Figure 2.

For free AChE, the $K_{m}$ and $V_{\max }$ values were found to be $2.3 \times 10^{-4} \mathrm{~mol} \mathrm{~L}^{-1}$ and $13.6 \mathrm{~mol} \mathrm{~L}^{-1} \mathrm{~min}^{-1}$, respectively. In the presence of copper(II), the result shows the same value of $K_{m}$ in comparison with the absence of copper(II) while the $V_{\max }$ continually decreases as the concentration of the inhibitor increases (Table $1(\mathrm{~A})$ ). The $K_{m}$ measured in this work is in good agreement with those obtained by Pohanka et al. [25] and Barteri et al. [26].

For enzyme immobilized on polymer monolith, the result shows the same value of $K_{m}$ in comparison with the free enzyme; however $V_{\max }$ decreased 7-fold. This is probably due to the presence of monolith affecting the degree of freedom of the enzyme and the enzyme not working under 


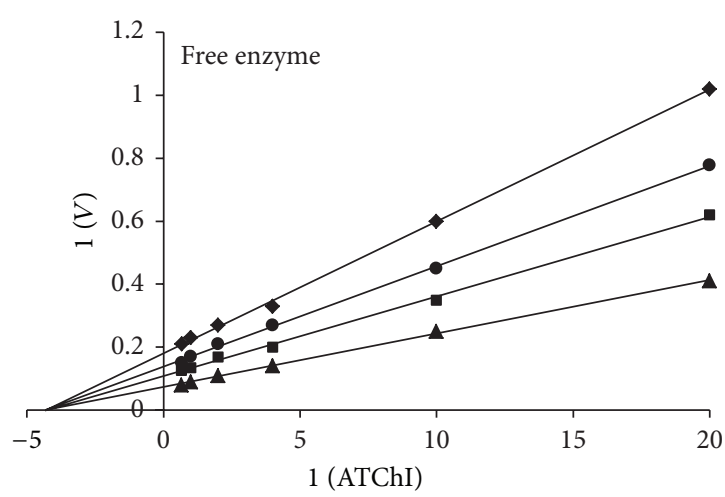

(a)

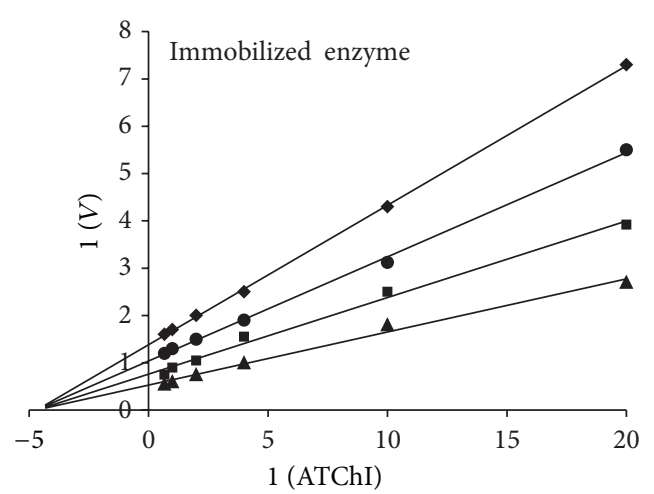

(b)

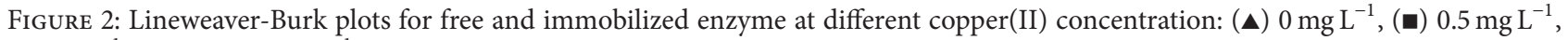
$1.0 \mathrm{mg} \mathrm{L}^{-1}$, and $(\diamond) 2.0 \mathrm{mg} \mathrm{L}^{-1}$.

diffusional control as expected with the free enzyme. In fact, this effect may be also associated with (a) differences in enzyme concentration, both immobilized and in solution, and (b) reduction in the $V_{\max }$ due to the substrate's inability to reach the active enzyme site by immobilization on the monolith [27]. For copper(II) the same inhibitory behavior could be observed, which caused the $K_{m}$ values to be constant and the $V_{\max }$ values to diminish when compared with the $K_{m}$ and $V_{\max }$ for immobilized AChE in the absence of inhibitor (see Table 1(B)).

The $K_{m}$ value of immobilized AChE measured in this experiment was similar to the free enzyme as described above, indicating that enzyme activity was maintained after immobilization. The Lineweaver-Burk plot obtained in Figure 2, both free and immobilized AChE, shows a typical noncompetitive inhibition. These results suggest that the inhibitor has no effect on the substrate binding after or before binding of the substrate, resulting in the formation of a catalytically inactive enzyme-substrate-inhibitor complex. In addition, copper(II), as a noncompetitive inhibitor, may interact with the enzyme at positions other than the catalytic active site [28]. The inhibition behavior of the copper(II) on AChE in this study was similar to those reported by Turdean and Popescu [29] which showed noncompetitive inhibition of heavy metal on AChE immobilized on Pt-nanoparticles modified graphite electrode.

\subsection{Investigation of Parameters for Heavy Metal Detection.} The operation conditions of the proposed FIA system and chemical variables were optimized using univariate method in order to achieve a high signal and reproducibility. Both chemical and flow variables were studied using the flow system shown in Figure 1. The poly(BuMA-co-EDMA) monolith with reactive poly(2-vinyl-4,4-dimethylazlactone) used in this work has a pore diameter distributions from 3 to $6 \mu \mathrm{m}$.

3.2.1. Effect of $p H$. The effect of $\mathrm{pH}$ of the phosphate buffer on the reaction between DTNB and thiocholine was first studied over the $\mathrm{pH}$ range of 5.0 to 9.0. The greatest absorption signal was obtained at $\mathrm{pH} 8.0$. Hence, $\mathrm{pH} 8.0$ was chosen as optimum.
3.2.2. Effect of Substrate Concentration. Effect of ATChI concentration on absorbance signal was investigated over the range of $0.5-20.0 \mathrm{mM}$. A phosphate buffer $(0.1 \mathrm{M} \mathrm{pH}$ 8.0) was used, against the DTNB concentration of $50 \mathrm{mg} \mathrm{L}^{-1}$ with a flow rate of $50 \mu \mathrm{L} \mathrm{min}^{-1}$. The absorbance increased with increasing ATChI concentration up to $10.0 \mathrm{mM}$; when the substrate concentration was greater than $10.0 \mathrm{mM}$, the absorbance increased slightly. However, a broadening of the peak shape was observed above $5.0 \mathrm{mM}$. Therefore, a concentration of $5.0 \mathrm{mM}$ of ATChI was fixed as a compromise between sensitivity, time consumption, peak shape, and substrate cost.

3.2.3. Effect of DTNB Concentration. The effect of DTNB concentration on the reaction of DTNB with thiocholine was studied in the range of $10-120 \mathrm{mg} \mathrm{L}^{-1}$. The greater absorbance is obtained when the concentration of DTNB increased up to $70 \mathrm{mg} \mathrm{L}^{-1}$ and after that the absorbance increased slightly. Thus, a concentration of DTNB at $70 \mathrm{mgL}^{-1}$ was chosen as optimum DT NB concentration to minimize the use of reagent.

3.2.4. Effect of Mixing Coil Length. The effect of mixing coil lengths was studied. Teflon tubing with a fixed inner diameter $(0.3 \mathrm{~mm}$ i.d.) but with different lengths was investigated for making mixing coil. This study was carried out at various mixing coil lengths between 10 and $50 \mathrm{~cm}$. The optimum lengths of the mixing coil selected for this experiment were $10 \mathrm{~cm}$ as a compromise between sensitivity and time consumption.

3.2.5. Effect of Flow Rate. The influence of flow rate of substrate and reagent solutions was studied. The flow rates were investigated over the range of $10-50 \mu \mathrm{L} \mathrm{min}^{-1}$ for both streams. The flow rate was limited by the level of back pressure through the system. The results showed that the enzyme activity was higher at lower flow rates owing to the increases in contact time between the enzyme and the substrate, which is more efficiently hydrolyzed and consequently the absorbance increased with lower flow rates. However, 
a broadening and tailing of the peaks shape was observed at lower flow rate, and therefore the highest flow rate possible was selected which also allowed a higher throughput.

The effect of the DTNB flow rate was examined. It was found that absorbance increased very rapidly from the DTNB flow rate of 10 to $20 \mu \mathrm{L} \mathrm{min}^{-1}$. After that, the absorbance was quite constant. Consequently, a DTNB flow rate of $20 \mu \mathrm{L} \mathrm{min}^{-1}$ was chosen as optimum.

To optimize the contact time between the enzyme (AChE) and the heavy metal (copper(II)), the effect of inhibitor flow rate was studied in the range of $1-10 \mu \mathrm{L} \mathrm{min}^{-1}$. The result showed that the inhibition percentage decreased with increasing inhibitor flow rate. This effect was expected as the key requirement to achieve sufficient contact time between the enzyme and the inhibitor. Therefore, the inhibitor flow rate at $5 \mu \mathrm{L} \mathrm{min}^{-1}$ was chosen as compromise between sensitivity, time consumption, and reduced toxic waste.

3.2.6. Effect of Injection Volume. The substrate and inhibitor volumes injected into the enzymatic system have a significant effect on absorbance signal. The effect of substrate injection volume on absorbance signal was studied by varying reagent volume of $20,40,60,80$, and $100 \mu \mathrm{L}$. As would be expected, the absorbance increased as the substrate volume increased; however, peak broadening was obtained leading to longer analysis time, and hence the sample throughput was decreased. In order to reach a reasonable compromise between sensitivity and response time or sample throughput a substrate volume of $40 \mu \mathrm{L}$ was chosen and used throughout the experiment. The effect of varying the inhibitor (copper(II)) injection volume was investigated from 20 to $100 \mu \mathrm{L}$ of $2.00 \mathrm{mg} \mathrm{L}^{-1}$ of copper(II) solution. The results suggested that a larger volume was preferable to obtain higher percentage inhibition; however, a $50 \mu \mathrm{L}$ was selected as a compromise between sensitivity and time consumption.

3.3. Enzyme Reactivation and Stability. Heavy metals have been known to inhibit cholinesterase. In this work, when the copper(II) is passed through the microreactor, the enzyme reactor is reversible inhibited by copper(II). Therefore, the enzyme restoration and operation stability of the proposed bioreactor were studied. AChE inhibition by heavy metal may be explained by the fact that heavy metals can bind to sulfhydrylic groups of enzymes [5] leading to the loss of enzyme function and subsequently resulting in decreases of absorbance. After the monolith based immobilized AChE bioreactor was contacted with a copper(II) $2.00 \mathrm{mg} \mathrm{L}^{-1}$ solution for $10 \mathrm{~min}, 95 \%$ of response was restored by washing with $0.5 \mathrm{M}$ EDTA solution, indicating that inhibition is reversible in this case. The same results were obtained by other authors $[13,30]$. A full and more rapid restoration of response is obtained by interaction of copper(II)-inhibited biosensor with strong ligands, an EDTA solution. In case of 50\% inhibition of copper(II) and restoring the bioreactor with a $0.5 \mathrm{mM}$ EDTA solution for $10 \mathrm{~min}, 95 \%$ of initial sensitivity restored but in case of $80 \%$ inhibition only $70 \%$.

A typical FIA signals behavior to the sequential exposure to ATChI substrate, copper(II), and EDTA is shown in

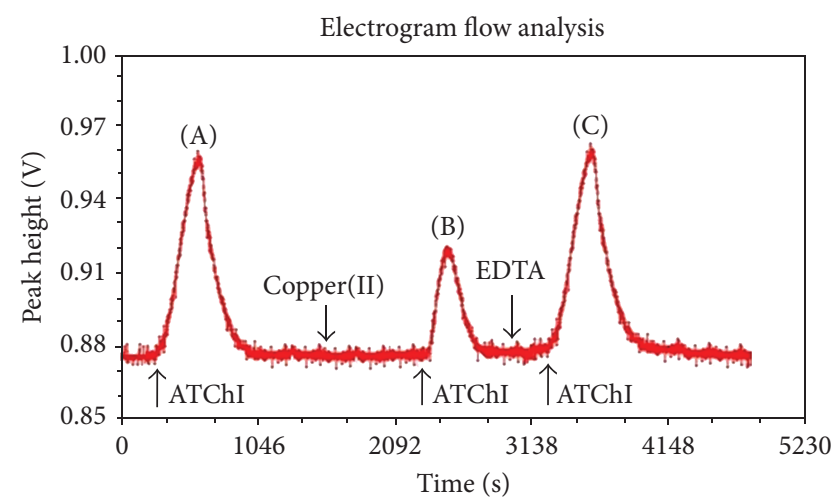

FIgURE 3: The FIA signals for the determination of copper(II) based on the inhibition of the enzymatic activity of AChE. In this case toward $5.0 \mathrm{mM}$ ATChI, $70 \mathrm{mg} \mathrm{L}^{-1} \mathrm{DTNB}, 2 \mathrm{mg} \mathrm{L}^{-1}$ copper(II), and 0.5 mM EDTA.

TABLE 2: Optimization parameters.

\begin{tabular}{lcc}
\hline Variable & Studies & Optimum \\
\hline $\mathrm{pH}$ & $5-9$ & 8 \\
Concentration of ATChI $/ \mathrm{mM}$ & $0.5-20$ & 5 \\
Concentration of DTNB $/ \mathrm{mg} \mathrm{L}^{-1}$ & $10-120$ & 70 \\
Mixing coil length $/ \mathrm{cm}$ & $10-50$ & 10 \\
Flow rate of ATChI $/ \mu \mathrm{L} \mathrm{min}^{-1}$ & $10-50$ & 50 \\
Flow rate of DTNB $/ \mu \mathrm{L} \mathrm{min}^{-1}$ & $10-50$ & 20 \\
\hline
\end{tabular}

Figure 3. A $40 \mu \mathrm{L}$ of $50 \mathrm{mM}$ ATChI substrate solution was injected to enzymatic flow-through reactor to initiate the enzyme reaction resulting in an increase in absorbance (A). After that a $50 \mu \mathrm{L}$ of a copper(II) solution $\left(2 \mathrm{mg} \mathrm{L}^{-1}\right)$ was injected. This results in a decrease in absorbance signal (B) owing to the inhibition of the enzyme by heavy metal. After the inhibition, $0.5 \mathrm{mM}$ of EDTA solution was passed through the bioreactor to restore enzyme activity resulting in an increase in absorbance signal when ATChI was again injected as the same concentration into the system (C). Each analysis cycle comprising the inhibition and restoration steps took about $15 \mathrm{~min}$.

The unused bioreactor when stored in the refrigerator at $4^{\circ} \mathrm{C}$ in phosphate buffer solution $(0.1 \mathrm{M}, \mathrm{pH} 7.0)$ containing $0.1 \%(\mathrm{w} / \mathrm{v})$ sodium azide can be used over a period of up to 7 weeks with the sensor response decreasing about $80 \%$. It suggests that the enzyme ageing is rely on its activity.

3.4. Analytical Characteristic. Using the above selected conditions (Table 2), a linear calibration curve over the range of $0.02-3.00 \mathrm{mg} \mathrm{L}^{-1}$ copper(II) was established which can be expressed by the regression equation $y=18.56 x+9.20$ $\left(r^{2}=0.9968\right)$, where $y$ represents the percentage of inhibition and $x$ is copper(II) concentration in $\mathrm{mg} \mathrm{L}^{-1}$. The repeatability was found to be $3.35 \%$ for the determinations of $1.00 \mathrm{mg} \mathrm{L}^{-1}$ copper(II) $(n=5)$. The detection limit, defined as the concentration of inhibitor required to obtain $10 \%$ of inhibition $\left(I_{10}\right)$, was $0.04 \mathrm{mg} \mathrm{L}^{-1}$ with a sample throughput of $4 \mathrm{~h}^{-1}$. 
TABLE 3: Percent recovery obtained from the proposed method for determination of copper(II) in water samples.

\begin{tabular}{|c|c|c|c|}
\hline \multirow[b]{2}{*}{ Samples } & \multicolumn{3}{|c|}{ Copper(II) } \\
\hline & $\begin{array}{l}\text { Added } \\
\left(\mathrm{mg} \mathrm{L}^{-1}\right)\end{array}$ & $\begin{array}{l}\text { Found } \\
\left(\mathrm{mg} \mathrm{L}^{-1}\right)\end{array}$ & $\begin{array}{c}\% \text { Recovery } \\
(\% \text { RSD }, n=2)\end{array}$ \\
\hline \multirow{2}{*}{1} & 0.50 & 0.48 & $96.0(2.92)$ \\
\hline & 2.00 & 1.99 & $99.5(2.38)$ \\
\hline \multirow{2}{*}{2} & 0.50 & 0.51 & $102.0(1.35)$ \\
\hline & 2.00 & 2.02 & $101.0(2.73)$ \\
\hline \multirow{2}{*}{3} & 0.50 & 0.52 & $104.0(3.24)$ \\
\hline & 2.00 & 1.95 & $97.5(2.95)$ \\
\hline
\end{tabular}

3.5. Application to Real Samples. The developed method was applied to the determination of copper(II) in natural water samples collected from Kuang River around the Northern Industrial Estate in Lamphun province. All water samples were filtered through Whatman No. 5 filter paper to remove particulates and before direct determination by the system. As might be expected no copper(II) was detected, and, therefore, the water samples were spiked with 0.50 and $2.00 \mathrm{mg} \mathrm{L}^{-1}$ of copper(II) and this experiment was analysed from 2 replicates of injection. Table 3 shows the precision and the recovery data obtained on water samples. The percentage recoveries were found to be between $96.0 \%$ and $104.0 \%$, showing that the proposed method could provide acceptable method efficiency, and recoveries of the added copper(II) by this analysis method were satisfactory.

The advantages of the present enzymatic FI procedure were simple (in situ monolith preparation and enzyme immobilization) and low chemicals consumption $\left(120 \mu \mathrm{L} \mathrm{sample}^{-1}\right.$ including all amounts of substrate, inhibitor, and reagent). So, the developed method could be considered to be more environmentally friendly due to providing cleaner analytical method for minimizing the use of sample and chemical reagent as well as reducing waste generation.

It should be noted that the inhibition of AChE is not given by only copper(II) but also by a lot of other heavy metals [31] as well as by organophosphate and carbamate pesticides [14]. However, the application of the proposed system in the determination of total toxic metal content, a valuable environment index, can be easily forecast.

\section{Conclusion}

A porous poly(BuMA-co-EDMA) monolith with reactive poly(2-vinyl-4,4-dimethylazlactone) chain for the in situ immobilization of AChE was successfully fabricated inside a capillary column. The monolith based immobilized AChE reactor was then incorporated into a flow injection system for the determination of copper(II) using spectrophotometric detection. The optimum conditions for copper(II) determination based on AChE inhibition were achieved. A linearity of the calibration graph over the range of $0.02-3.00 \mathrm{mg} \mathrm{L}^{-1}$ was obtained with a detection limit of $0.04 \mathrm{mg} \mathrm{L}^{-1}$. Regarding the reduction of chemical consumption and waste production, the proposed system can be used for an alternative green analytical chemistry.

\section{Conflict of Interests}

The authors declare that there is no conflict of interests regarding the publication of this paper.

\section{Acknowledgments}

The authors would like to gratefully acknowledge the School of Science, Walailak University. Some of the devices and Windows applications were developed in cooperation with Alpha flow research, Chiang Mai University.

\section{References}

[1] M. E. Ghica, R. C. Carvalho, A. Amine, and C. M. A. Brett, "Glucose oxidase enzyme inhibition sensors for heavy metals at carbon film electrodes modified with cobalt or copper hexacyanoferrate," Sensors and Actuators B, vol. 178, pp. 270278, 2013.

[2] T. I. Godjevargova, K. I. Gabrovska, and N. V. Ivanova, "Copper(II) determination by immobilized urease inhibition in a spectrometric flow-injection system," Biotechnology and Biotechnological Equipment, vol. 19, no. 2, pp. 202-210, 2005.

[3] O. O. Soldatkin, I. S. Kucherenko, V. M. Pyeshkova et al., "Novel conductometric biosensor based on three-enzyme system for selective determination of heavy metal ions," Bioelectrochemistry, vol. 83, no. 1, pp. 25-30, 2012.

[4] A. M. Salgado, L. M. Silva, and A. F. Melo, Biosensor for Environmental Applications, edited by: V. Somerset, Chapter 1, InTech, 2011.

[5] A. Amine, H. Mohammadi, I. Bourais, and G. Palleschi, "Enzyme inhibition-based biosensors for food safety and environmental monitoring," Biosensors and Bioelectronics, vol. 21, no. 8, pp. 1405-1423, 2006.

[6] L. M. May and D. A. Russell, "Novel determination of cadmium ions using an enzyme self-assembled monolayer with surface plasmon resonance," Analytica Chimica Acta, vol. 500, no. 1-2, pp. 119-125, 2003.

[7] H.-C. Tsai and R.-A. Doong, "Simultaneous determination of $\mathrm{pH}$, urea, acetylcholine and heavy metals using array-based enzymatic optical biosensor," Biosensors and Bioelectronics, vol. 20, no. 9, pp. 1796-1804, 2005.

[8] A. P. Soldatkin, V. Volotovsky, A. V. El'Skaya, N. JaffrezicRenault, and C. Martelet, "Improvement of urease based biosensor characteristics using additional layers of charged polymers," Analytica Chimica Acta, vol. 403, no. 1-2, pp. 25-29, 2000.

[9] C. Malitesta and M. R. Guascito, "Heavy metal determination by biosensors based on enzyme immobilised by electropolymerisation," Biosensors and Bioelectronics, vol. 20, no. 8, pp. 1643-1647, 2005.

[10] H. Mohammadi, A. Amine, S. Cosnier, and C. Mousty, "Mercury-enzyme inhibition assays with an amperometric sucrose biosensor based on a trienzymatic-clay matrix," Analytica Chimica Acta, vol. 543, no. 1-2, pp. 143-149, 2005.

[11] P. W. Alexander and G. A. Rechnitz, "Enzyme inhibition assays with an amperometric glucose biosensor based on a thiolate 
self-assembled monolayer," Electroanalysis, vol. 12, no. 5, pp. 343-350, 2000.

[12] H. Mohammadi, M. El Rhazi, A. Amine, A. M. Oliveira Brett, and C. M. A. Brett, "Determination of mercury(II) by invertase enzyme inhibition coupled with batch injection analysis," Analyst, vol. 127, no. 8, pp. 1088-1093, 2002.

[13] G. A. Evtyugin, I. I. Stoikov, G. K. Budnikov, and E. E. Stoikova, "A cholinesterase sensor based on a graphite electrode modified with 1,3-disubstituted calixarenes," Journal of Analytical Chemistry, vol. 58, no. 12, pp. 1151-1156, 2003.

[14] B. Prieto-Simón, M. Campàs, S. Andreescu, and J.-L. Marty, "Trends in flow-based biosensing systems for pesticide assessment," Sensors, vol. 6, no. 10, pp. 1161-1186, 2006.

[15] B. Kuswandi, "Simple optical fibre biosensor based on immobilised enzyme for monitoring of trace heavy metal ions," Analytical and Bioanalytical Chemistry, vol. 376, no. 7, pp. 11041110, 2003.

[16] P. A. Levkin, S. Eeltink, T. R. Stratton et al., "Monolithic porous polymer stationary phases in polyimide chips for the fast highperformance liquid chromatography separation of proteins and peptides," Journal of Chromatography A, vol. 1200, no. 1, pp. 5561, 2008.

[17] B. Ngamsom, A. M. Hickey, G. M. Greenway, J. A. Littlechild, P. Watts, and C. Wiles, "Development of a high throughput screening tool for biotransformations utilising a thermophilic 1-aminoacylase enzyme," Journal of Molecular Catalysis B, vol. 63, no. 1-2, pp. 81-86, 2010.

[18] P. Rattanakit, G. M. Greenway, and S. Liawruangrath, "Development and evaluation of microfluidic device for the determination of organophosphorus pesticide incorporating monolith based immobilized AChE with spectrophotometric detection," International Journal of Environmental Analytical Chemistry, vol. 93, no. 7, pp. 739-754, 2013.

[19] D. S. Peterson, T. Rohr, F. Svec, and J. M. J. Fréchet, "Dualfunction microanalytical device by in situ photolithographic grafting of porous polymer monolith: integrating solid-phase extraction and enzymatic digestion for peptide mass mapping," Analytical Chemistry, vol. 75, no. 20, pp. 5328-5335, 2003.

[20] D. S. Peterson, T. Rohr, F. Svec, and J. M. J. Fréchet, "Enzymatic microreactor-on-a-chip: protein mapping using trypsin immobilized on porous polymer monoliths molded in channels of microfluidic devices," Analytical Chemistry, vol. 74, no. 16, pp. 4081-4088, 2002.

[21] G. L. Ellman, K. D. Courtney, V. Andres Jr., and R. M. Featherstone, "A new and rapid colorimetric determination of acetylcholinesterase activity," Biochemical Pharmacology, vol. 7, no. 2, pp. 88-95, 1961.

[22] T. C. Logan, D. S. Clark, T. B. Stachowiak, F. Svec, and J. M. J. Fréchet, "Photopatterning enzymes on polymer monoliths in microfluidic devices for steady-state kinetic analysis and spatially separated multi-enzyme reactions," Analytical Chemistry, vol. 79, no. 17, pp. 6592-6598, 2007.

[23] P. Masawat, S. Liawruangrath, and S. Upalee, "Spectrophotometric flow-injection analysis assay of tetracycline antibiotics using a dual light-emitting diode based detector," Maejo International Journal of Science and Technology, vol. 2, no. 1, pp. 201209, 2008.

[24] H. Lineweaver and D. Burk, "The determination of enzyme dissociation constants," Journal of the American Chemical Society, vol. 56, no. 3, pp. 658-666, 1934.
[25] M. Pohanka, M. Hrabinova, K. Kuca, and J. Peirre-Simonato, "Assessment of acetylcholinesterase activity using indoxylacetate and comparison with the standard ellman's method," International Journal of Molecular Sciences, vol. 12, no. 4, pp. 2631-2640, 2011.

[26] M. Barteri, A. Pala, and S. Rotella, "Structural and kinetic effects of mobile phone microwaves on acetylcholinesterase activity," Biophysical Chemistry, vol. 113, no. 3, pp. 245-253, 2005.

[27] M. F. Cabral, L. F. Sgobbi, E. M. Kataoka, and S. A. S. Machado, "On the behavior of acetylcholinesterase immobilized on carbonnanotubes in the presence of inhibitors," Colloids and Surfaces B, vol. 111, pp. 30-35, 2013.

[28] A. Al-Aboudi, H. Odeh, A. Khalid, Q. Naz, M. I. Choudhary, and A.-U. Atta-Ur-Rahman, "Butyrylcholinesterase inhibitory activity of testosterone and some of its metabolites," Journal of Enzyme Inhibition and Medicinal Chemistry, vol. 24, no. 2, pp. 553-558, 2009.

[29] G. L. Turdean and I. C. Popescu, "Electrochemical method for heavy metals detection by inhibition of acetylcholinesterase immobilized on pt-nanoparticles modified graphite electrode," in Proceedings of the 16th International Conference on Heavy Metals in the Environment, vol. 1, no. 05007, pp. 1-3, 2013.

[30] M. Stoytcheva, "Electrochemical evaluation of the kinetic parameters of a heterogeneous enzyme reaction in presence of metal ions," Electroanalysis, vol. 14, no. 13, pp. 923-927, 2002.

[31] D. Lima, G. M. Roque, and E. A. Almeida, "In vitro and in vivo inhibition of acetylcholinesterase and carboxylesterase by metals in zebrafish (Dano rerio)," Marine Environmental Research, vol. 91, pp. 45-51, 2013. 

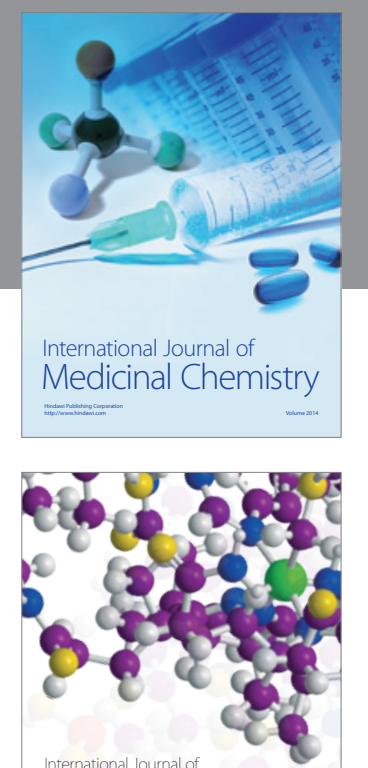

\section{Carbohydrate} Chemistry

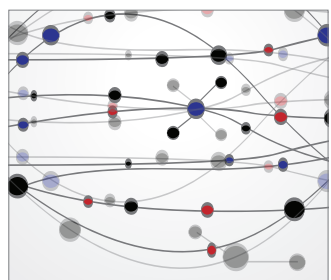

The Scientific World Journal
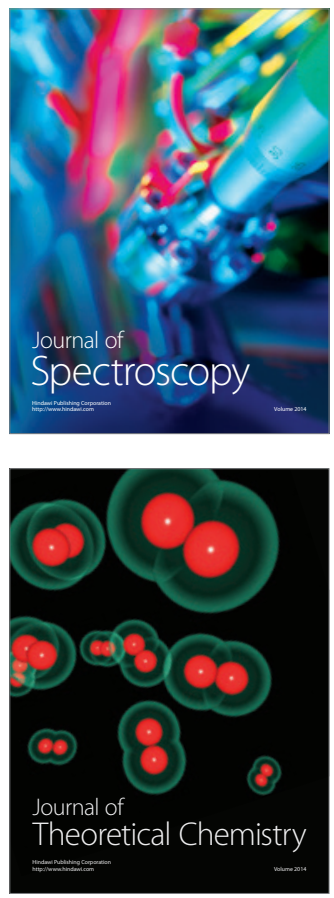
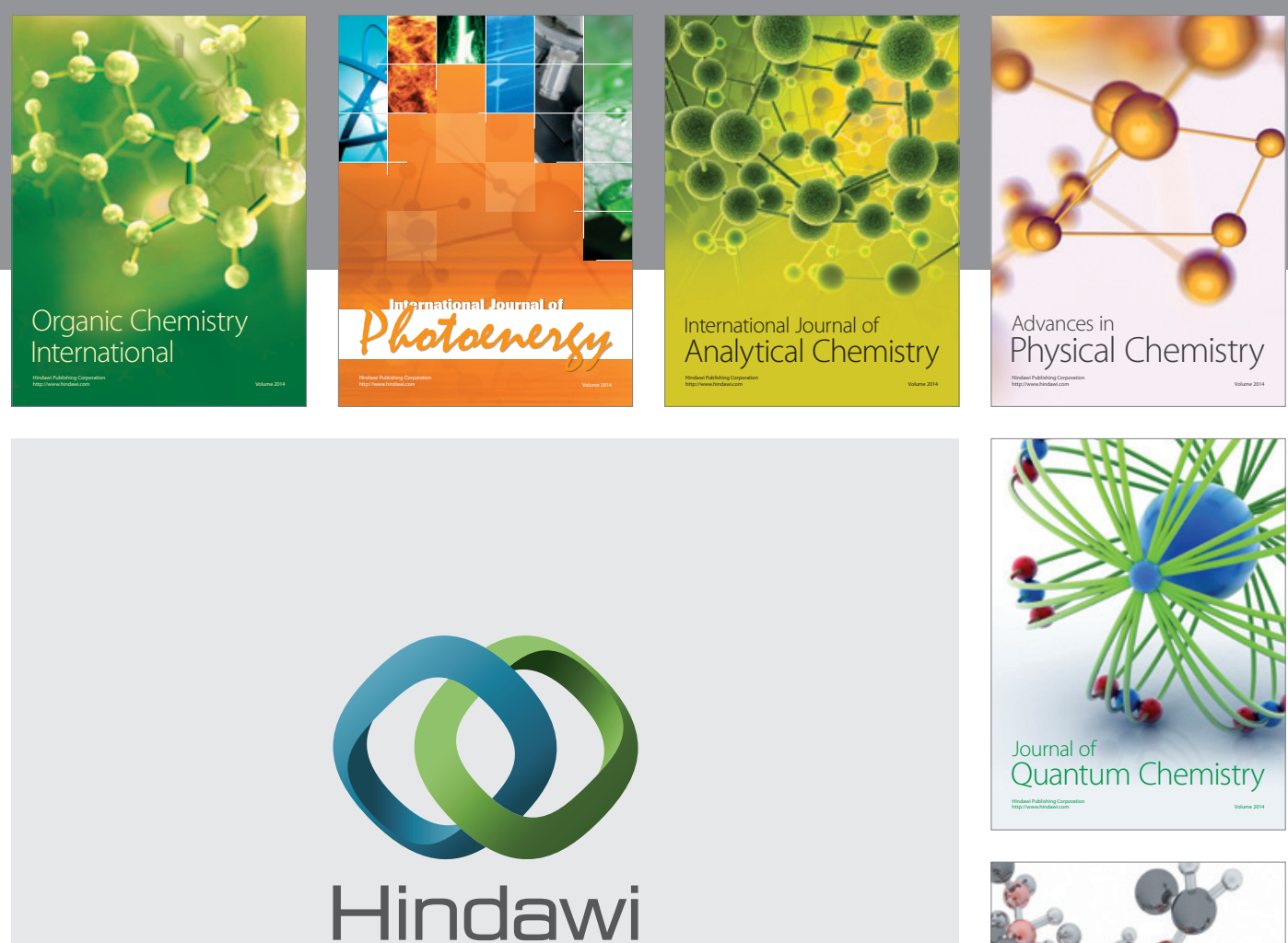

Submit your manuscripts at

http://www.hindawi.com

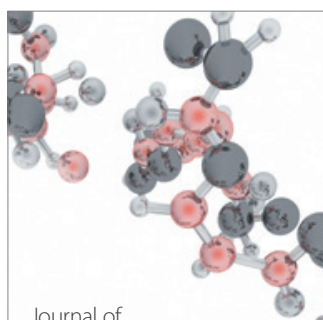

Analytical Methods

in Chemistry

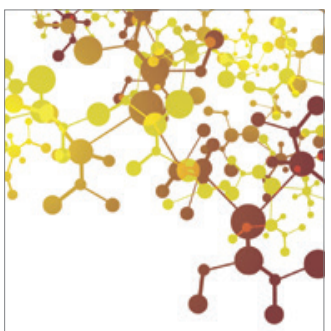

Journal of

Applied Chemistry

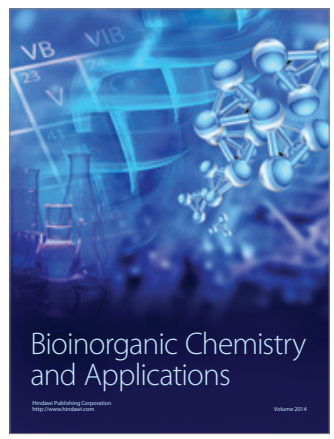

Inorganic Chemistry
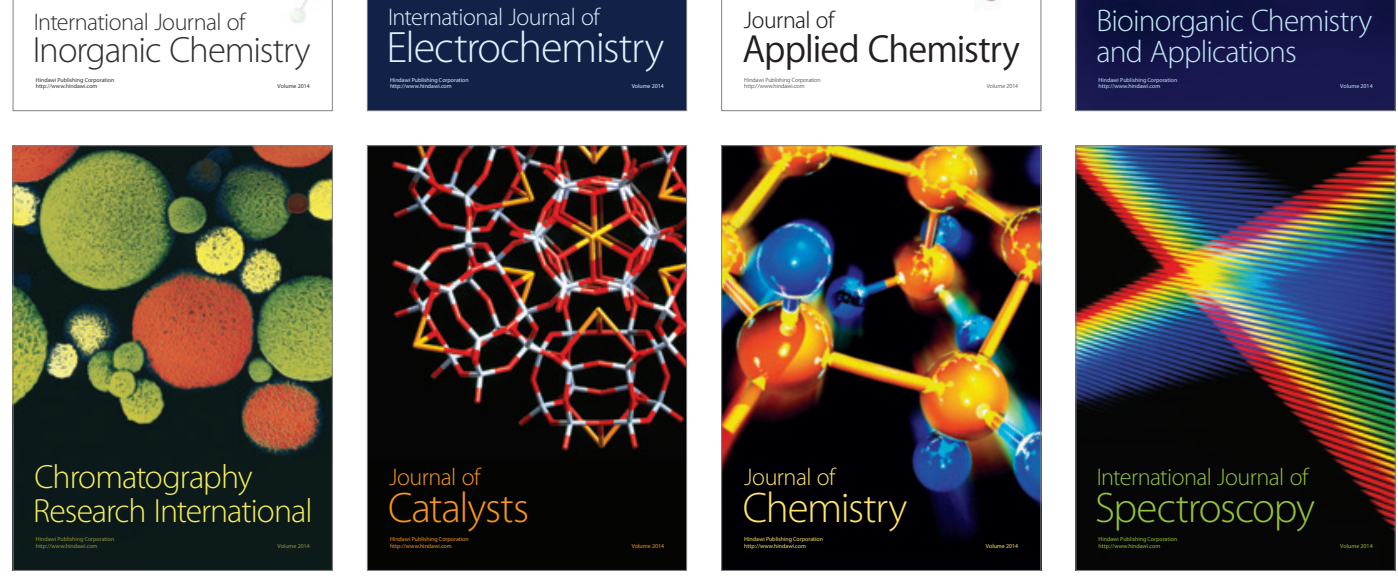